\title{
Ismertetés: Az egészségműveltség iskolákban történő fejlesztésének etikai alapjai: érvek („miért”), irányok („mit”) és hangszínek („hogyan”)
}

\author{
Ethical underpinnings for the development of health literacy in schools: ethical \\ premises ('why'), orientations ('what') and tone ('how')
}

Ismerteti: $\quad$ Szabó Tímea Pálma $₫$

Pécsi Tudományegyetem, Általános Orvostudományi Kar, Orvosi Népegészségtani Intézet

Szerzők: Leena Paakari, Shanti George

Megjelenés: BMC Public Health. 2018;18:326. doi: 10.1186/s12889-018-5224-0

Beküldve: 2018. 07. 31.

doi: $10.24365 /$ ef.v59i4.342

Kulcsszavak: egészségmúveltség; etika; oktatás

Keywords: health literacy, ethics, education

\section{BEVEZETÉS}

Az elmúlt évek kutatásai során egyre nagyobb figyelmet kapott az egészségműveltség témája, azonban az ezzel kapcsolatos erkölcsi megfontolásokra nem került megfelelő hangsúly. A gyermekek egészségi állapota és egészségműveltsége kiemelt fontosságú a népesség jólétének, egészségének javítása szempontjából, az iskolák pedig fontos színterei a különböző egészséggel kapcsolatos kompetenciák fejlesztésének. Az oktatás alapvetően egy morálisan terhelt hivatás, az egészséggel kapcsolatos ismeretek tanítása pedig külön erkölcsi kérdéseket vet fel. A megfelelő szintű egészségműveltség elérése egyéni és társadalmi szinten is jelentős előnyökkel bír: többek között jobb egészségi állapottal, valamint alacsonyabb egészségügyi költségekkel függ össze; nem csoda, hogy számos országban kifejezett népegészségügyi célként tűzték ki az egészségmúveltség társadalmi szintű fejlesztését. Az elmúlt másfél évtized során jelentős erőfeszítéseket fordítottak az egészségmüveltség felmérésére is, hogy a politikai vezetés képet kaphasson annak aktuális szintjéről a különböző populációkban.

\section{MIÉRT FONTOS A TANULÓK EGÉSZSÉGMŰVELT- SÉGÉNEK FEJLESZTÉSE?}

A magasabb szintű egészségmúveltség nagyobb mértékű függetlenséget tesz lehetővé, autonómiát és szabadságot biztosít. Ez alapján az egészségmüveltségre, mint alapvető jogra tekinthetünk: mindenkinek joga van tudni, hogyan fejlesztheti a saját és mások egészségét, hogyan előzheti meg a betegségeket, vagy mit tehet gyógyulása érdekében; az egészséggel kapcsolatos ismeretek oktatásának elmulasztása ezáltal erkölcsi szempontból problémás.

A jó egészségi állapotról alkotott elképzeléseket általában tekintélyelvű, tényszerü bizonyosságokat tartalmazó irányelvekbe fordítják, melyek az előnyösnek, vagyis követendőnek tartott és a hátrányos, ezáltal szankcionálandó magatartásformákról határozott állásponttal rendelkeznek. Ezen gondolat mentén felvetődik a kérdés, hogy pontosan mit is tekintünk egészségnek vagy egészségességnek, és ki állapítja meg, hogy milyen viselkedésformák a preferálandók, továbbá személyes felelőssége-e az egyéneknek egészséges életmódot folytatni? Az oktatás általánosságban 
javítja az egészségi állapotot és a jólétet, az egészségműveltséggel kapcsolt készségek iskolákban történő fejlesztése pedig csökkentheti a különböző társadalmi-gazdasági háttérrel bíró gyermekek közötti egyenlőtlenségeket.

Az oktatási kimenetelek tekintetében a gazdagabb és szegényebb rétegek között nagy, és egyre növekvő különbségek vannak. Napjainkban közelítőleg 1,7 millió gyermek számára nem biztosított a közoktatás, holott az írástudás alapvető emberi jog. Emellett az iskolák különböző felszereltsége, illetve a gyerekekre fordított erőforrásbeli különbségek miatt az iskolákban a tanulók információhoz való hozzáférése rendkívül egyenlőtlen, melyet a technológiai fejlődés tovább fokoz. Ezért is rendkívül fontos, hogy mi kerül be az általános tantervbe, hiszen ha csupán egyes országokban vagy térségekben oktatnak egészségismereteket, az tovább növelheti a különbségeket. Az egyenlő esélyek kialakítása érdekében ezáltal az általános oktatás egészségismeretekkel történő kiegészítése mellett a veszélyeztetett, alacsonyabb társadalmigazdasági státuszúak körében végzett célzott intervenció lenne célravezető. Ezzel párhuzamosan a különböző marginalizált csoportok integrációja is segítené a hiátus további csökkentését.

\section{MIT SZÜKSÉGES HANGSÚLYOZNI AZ EGÉSZSÉGMŰVELTSÉG TANTERVÉBEN?}

A szerzők érvelése szerint a konkrét, memorizálandó adatok átadása helyett az egészségműveltség fejlesztésében a kritikus gondolkodásra nevelés volna a célszerű. Morális tekintetben az iskolák és tanárok feladata az egészséggel kapcsolatos döntéshozatalt támogató, arra képessé tevő oktatás megszilárdítása. Napjaink problémáját nem az információhiány vagy az információszerzési képesség elégtelensége okozza, hanem az adatok sokaságának nem megfelelő használata, illetve azok minőségének, hitelességének hibás megítélése. Az egészségügyben jellemző, sokszor kiszámíthatatlan kihívásokban történő helytálláshoz komplex készségek szükségesek, azt pedig az adott helyzet kontextuális tényezői határozzák meg, hogy aktuálisan melyek ezek. Vitatható, hogy felállítható-e egy standard lista, mely az összes potenciálisan szükséges készséget tartalmazza, hiszen az a valóságtól túlságosan elrugaszkodott, teoretikus volna. Ehelyett a szerzők univerzális kulcskompetenciákat azonosítanak, melyek iskolai környezetben történő fejlesztése elengedhetetlen: ezek a kritikai gondolkodás, az öntudatosság és az állampolgári kompetenciák. Ezek összességében az autonóm tanulást, valamint az egyéni hatóképesség, a vizsgálódó szemlélet és a felelős állampolgári beállítódás kialakulását segítik. A kritikai gondolkodás a tudást folyamatos újraértékelésnek veti alá, szkeptikus attitűdöt képvisel, valamint elismeri az emberi ügyek komplexitását. Az öntudatosság reflexív és reflektív készségeket takar - saját preferenciák, értékek, saját identitás, autonómia kialakítása, illetve az egyén világban betöltött pozíciójának a felismerése. Az állampolgári kompetenciák pedig az ember saját útjának megtalálását, a társadalom hasznos tagjává válást, illetve az erkölcsileg felelősségteljes módon történő cselekvést foglalja magában.

\section{HOGYAN KÖZELITTSÜK MEG AZ EGÉSZSÉGMŰ- VELTSÉG TÉMÁJÁT AZ ISKOLÁKBAN?}

A társadalmi igazságosság eszméje előbbre való a puszta költséghaszon-megfontolásoknál az egészségmúveltség oktatásának szempontjából. Az erkölcsi orientációjú oktatás nyitott, érdeklődő közösségben zajlik, ahol mindenki a csoport egyenlő tagjaként van jelen. Az információ szabadsága, ezáltal a gondolkodás szabadsága jellemzi az ideális közeget, mely egyben bátorítja a különböző világnézetek kialakítását, támogatja a személyiség és az autonómia kifejlesztését. A szerzők a „fegyelmezett szabadság” értékét hangsúlyozzák a határok nélküli szabadság vagy a merev keretek felett. A tanárok feladata a tudás komplexitására és a tények megkérdőjelezhetőségére tanítani a diákokat, mely tekintetben a kritikai gondolkodásra nevelés és az egyéni reflexió elengedhetetlen fontosságú. A cél egy elfogadó, nyitott közeg kialakítása, melyben a diákok sokszínúsége, egymástól különböző háttere és tapasztalatai egymást gazdagító értékekként vannak jelen; ők egymásra nem csupán osztálytársakként, hanem a társadalom egyenrangú tagjaiként tekintenek. 


\section{TANULSÁGOK A HAZAI SZAKEMBEREK SZÁMÁRA}

Az egészségmegőrzéshez- és fejlesztéshez szükséges kompetenciák kialakítása rendkívüli fontosságú, azonban ennek etikai háttere mindezidáig nem kapott kellő figyelmet, noha az erkölcsi megfontolások központi szerepet érdemelnek a társadalmi igazságosság érdekében. Az egészségismeretek közoktatásba történő bevétele, illetve a kapcsolt kompetenciák kialakítása nagyban segíthetnek a társadalom egészségmúveltségének fejlesztésében, mely ezáltal számos egyéni és populációs szintű haszonnal kecsegtet. 